\title{
THE ETHICAL ASPECTS OF TECHNO-SCIENCE, DROMOLOGY, AND HYPERREALITY
}

The contemporary societies are characterized by several attributes. We can talk about a postmodern, scientific-technical, information, fast, hyperreal or consumer society. In fact, these attributes do not appear in isolation, but in relation to each other. The author inspired by postmodernists such as Lyotard, Virilio, and Baudrillard, focuses on identifying the ethical aspects of these phenomena and deals with the contemporary image of man and societies in this context. Science, technology, information and communication technologies permeate all spheres of human being and change the nature of knowledge. Information, time and speed are important factors and manipulation with them is a key way of ordering societies and shaping the image of man. We may call this an ability to transform reality and create hyperreality. Hyperreality may also be referred to as the paradigm of the current cultural situation of consumerism.

Keywords: postmodern age, techno-science, dromology, hyperreality, technologies, knowledge, image of a man

\section{Introduction}

For the last decades, the whole world or, as McLuhan would say, the whole "global village" faces dynamic changes in social, economic, cultural and moral spheres. [1, p. 31]. These changes are, of course, accompanied by new phenomena and new conceptual models. We are facing a varied palette of expressions that influence thinking of the individual and society, so we can observe that our cultural area is also being discussed in the concept of a new socio-cultural paradigm. Several attributes characterize the contemporary societies; we can talk about a postmodern, scientific-technical, information, fast, hyperreal or consumer society. In fact, these attributes do not appear in isolation, but in relation to each other. Nowadays we are living at a relatively high level of science and technology development. Science has gained a pragmatic character, and the information and communication technologies infiltrate not only all structures of society but also all human affairs, the everyday lives of all people. We are surrounded by a tsunami of information that we are not able to critically evaluate. The most important factors are time and speed. The manipulation with these factors becomes a key way of organizing and profiling society, and it also participates in the shaping of the image of man. The term hyperreality is typical for these societies and the semiotics of their philosophy. This phenomenon can be described as an inability to distinguish reality from fantasy or fiction. The media and various information and communication technologies have the ability to transform and change reality and create the so-called hyperreality. This fact makes it impossible for the media users to make a critical and objective evaluation of reality. Consequently, we can also consider hyperreality as a paradigm explaining the current cultural state for which consumerism is typical.

This contribution aims to analyze the phenomena of technoscience, dromology, and hyperreality in their mutual correlation and their subsequent interpretation in the context of their ethical aspects and consequences. The methodology of the work focuses on the analysis and interpretation of works of influential authors. Specifically, the work of Lyotard focuses on the phenomenon of techno-science in the context of postmodernism (2). In this sense, we discuss Virilio's dromology that deals with the relationship of time, speed, place, reality, truth (3) to arrive at Baudrillard's understanding of hyperreality (4). These French thinkers critically analyze the postmodern societies, culture and ethical atmosphere.

\section{Techno-science and the "Inhuman"}

"Knowledge is and will be produced in order to be sold, it is and will be consumed in order to be valorized in a new production: in both cases, the goal is exchange." [2, p.4 ].

Jean-Francois Lyotard [3]

\footnotetext{
* Livia Sebikova

The Department of General and Applied Ethics at the Faculty of Arts, Constantine the Philosopher University in Nitra, Slovakia

E-mail: livia.sebik@gmail.com
} 
We consider it necessary to state in the very beginning that our understanding of computerized societies and techno-science will be perceived in a postmodern context as was understood by Lyotard. Lyotard uses the prefix "post-" to demonstrate his understanding of postmodernism as "an incredulity toward metanarratives. This incredulity is undoubtedly a product of progress in the sciences: but that progress in turn presupposes it.“[2, p. xxiv]. In Postmodern Situations the author develops his reflections on science and technology. This changing state of science is, according to him, one of the main features of the postmodern era and influences knowledge as such. The term "information" is extremely frequent today. The process of informatization has affected every sphere of the human life in both the individual and social dimensions. Information is an important component of knowledge but as we can see its nature changes and its value becomes more progressive. The Lyotard's hypothesis is that knowledge changes its status as societies enter into the postindustrial age and postmodern age. The technological transformations which are also increasingly revolutionary influence knowledge in two basic functions - in research, which we can see in the development of new scientific disciplines but also in the transmission of acquired learning. [2, p. 4]. Information or knowledge becomes available and therefore relevant only when it is transferred to an information quantum. Knowledge depends on the technology. It may be assumed that the logic of knowledge follows the principle that what is not presented in the "machine language," will be eliminated from knowledge. "We can predict that anything in the constituted body of knowledge that is not translatable in this way will be abandoned and that the direction of new research will be dictated by the possibility of its eventual results being translatable into computer language." [2, p. 4]. The demand for operability of knowledge requires an ever-more progressive development of technology. The changing nature of knowledge also changes its function. Knowledge is no longer an enriching, educational or educative element, it does not fulfill its purpose but it becomes a good circulated on the market. Therefore, "knowledge is and will be produced in order to be sold, it is and will be consumed in order to be valorized in a new production: in both cases, the goal is exchange.” [2, p. 4]. So what are the consequences of these changes?

Lyotard uses the term "techno-science" to identify the forces that act towards expanding the technology at the expense of humanity and its values. The hand of development is hiding above such an imperative that primarily focuses on the cultivation of dominance over an increasingly hostile background through a massive increase of the system efficiency. The development of techno-science is not only related to the contemporary postmodern age. On the contrary, it was modernism that glorified human reason, science, progress and the enlightenment morality. Modernism understood progress in the sense of humanity's emancipation. The human being should be exempted from oppression, ignorance, bad social status, etc. However, the danger that comes along with this progress represents ever-greater alienation of man from himself. As Turcan points out, "The essence of modern technology thus rests in its alienation from humans." [4, p. 36]. The techno-science under the pressure of "blind" progress as its main intendant, deals with improving the operational efficiency of technological systems, so the man becomes irrelevant in this process. The progress wants to continue indefinitely in the expansion and anything that hinders development, and these internal dynamics is considered as a problem that needs to be overcome by achieving ever greater operational efficiency. We can assume that the techno-science has absorbed us so much that it has become self-regulatory and self-serving and it rather contributes to our lack of freedom. We have become indifferent to its progress, and we shape ourselves in accordance with its trends in the material, psychological, physical and moral terms. Lyotard himself calls for a campaign against the techno-science and all of its activities. His concerns are related to the establishment of "inhumanity" [5]. This specific term designates all such cases when the human dimension is overshadowed by a technical side, or when the human side appears inferior to the technical in some way. Our lives are increasingly influenced by the selfregulatory machinery of progress. Our aim is not to formulate some futuristic thoughts about machine dominance; we would merely like to point out that we have become "dehumanized" by the forces of technological progress, disregarding our real vision of the world and the authenticity of the human being. Thanks to minimal control over the potentialities and consequences of this progress we find ourselves in the culture of the inhuman. The techno-science strives for control in the sense of uniformity, which totally excludes our postmodern enthusiasm for differences. The message is clear: thinking should not be separated from the body. The progress of technology and new means of communication forms "new" thinking or rather "non-thinking" and influences the perception of reality and the image of the humanity of the postmodern age that is also related to the phenomenon of speed. We will thus try to clarify it the next section.

\section{Dromology: time - speed - place - reality - truth}

„Without even suspecting it, we have become the heirs and descendants of some fearsome antecedents, the prisoners of hereditary defects transmitted now not through the genes, sperm or blood, but through an unutterable technical contamination." [6, p. 39]

Paul Virilio [7]

The term "dromology" (from Greek dromos - run, race) was introduced by Virilio in 1977. The speed, the ways of its transformation and the transformation of those who are in its captivity, is a basic idea of the author's work. With Virilio's optics, we may ask questions such as: How is the speed of movement associated with time and with the survival of temporality? 
Which socio-political consequences result from the continuous acceleration of social processes? How is technology affecting people? Virilio deals with the relationship: time - speed - place - reality - truth. In many places, we find his critical attitude to new technologies and technological progress which has left us trapped in the techno-totality. According to Virilio, "Without even suspecting it, we have become the heirs and descendants of some fearsome antecedents, the prisoners of hereditary defects transmitted now not through the genes, sperm or blood, but through an unutterable technical contamination.” (6, p. 39). Virilio's view of the present says that the world war has long been declared and even more than in any other war, it's first victim is the truth. The progress of technology has caused the human to no longer be able to determine what exists and what does not. He has renounced himself as the center of energy and stopped to perceive the world as depending on his being. The ability to perceive our individuality was transferred to machines, sensors, detectors, etc. Technologies have "killed" the present time and created a new "non-time communication space." Our relationship to the world was replaced by virtuality, which is controlled only by some abstraction of time for which no one is directly responsible. Virtuality has the potential to destroy the deontological foundations of the truth and reality. Our geophysical state is not important for us; the cyberspace is becoming an important factor where the whole reality, the realities of things and human beings, the socio-cultural phenomena are accelerating. For Virilio, this means a systemic risk because it develops into blindness, the blindness of humanity, the unpleasant possibility of defeating the facts and thus the disorientation in our relating to reality which necessarily impacts the history of humanity. A levitating history of the present age is based solely on the tele-presence of events which, in fact, do not follow one another because the moment of instance already defeats the depth of the historical succession. It comes to the deconstruction of the space-time dimensions. By continually introducing higher speed, we discredit the value of some action and thus we abandon the ability to act in favor of our ability to respond. The Virilio's main concern is related to the "automatable processing of knowledge," that generalization of amnesia which will be the ultimate achievement of the oblivion industry, (...)". [6, p. 123]. The number with its unlimited mathematical power denies phenomenology of the real world. The phenomena have hidden behind the calculus that exceeds the speed of any intelligent contemplation. Virilio examines the contradiction between the natural world and its technically mediated representation. It implies that the overlapping of the physical world with the virtual world can lead to a complete disorientation of man, but also to an absolute control over his being.

Virilio's concept of dromology can be considered as aesthetics of disappearance, and this is related to the image of the human in the postmodern age. Virilio [8] focuses on a phenomenom of "piknolepsia" [9], but he does not deal with this as a disease.
According to him, this is the origin of the disappearance which has significant importance for knowledge and our perception of reality. The crucial question bears on the loss of ability to perceive reality. Virilio demonstrates the piknolepsia as a mass phenomenon. The moments of vigilance alternate between our piknoleptic moments. So our knowledge, consciousness, and perception of reality are created by the discontinuous moments influenced by the speed factor. The speed is a fundamental reason why we feel that something is still missing. The piknoleptics still need to produce their own reality because of the failures to perceive reality in order to be able to cope with their being. So the real reality is replaced and the "best reality" is produced by this illusion. This kind of illusion results in its own construction. This constructed reality absorbs fundamental facts of the world. We are pushed into a culture of gambling and accident by this kind of progress of knowledge. Virilio points out that postmodern people and societies have voluntarily destroyed reality by the manipulation of speed. It brings about the problem of realizing what is real, and distinguishing it from what is invented, random, intended, artificially produced; what is the original or the copy. The postmodern picnoleptics become disoriented. They are lost in the real world in which they cannot control the spacetime dimension, so they cease to know the real circumstances, causes, and consequences of their decisions. The technological progress also causes that our senses are unreliable and dull and they do not actually see the reality. A man is everywhere and nowhere. He or she is full of images, emotions, thoughts, but they are empty. We are no longer in the reality but in hyperreality. In order to demonstrate this postmodern concept, we will focus on Baudrillard's understanding of hyperreality as a paradigm explaining the current moral-cultural conditions.

\section{Hyperreality or simulacrum is real}

„The real is not only what can be reproduced, but that which is already reproduced, the hyper-real." [10, p. 146]

Jean Baudrillard [11]

Baudrillard's basic philosophical vocabulary reservoir is filled by the following terms and themes: the power of objects, estrangement, simulation and disappearing of reality, reversibility, misleading, anesthetization, hyperreality, simulacra, semiocracy, the ecstasy of reality, virality, virtuality, implosion, seriality, transpolitical, obscene. Baudrillard tracked and uncovered these mentioned phenomena in various areas of sociality - sexuality, morality, politics, etc. Baudrillard's reader gets an impression that simulation is the general epistemological code for observing the world where a huge confederacy of signs took place, and these signs are like satellites rotating over the disappearing reality. Considering the topic of our paper, we focus on the phenomena of the sign, simulation, simulacrum and hyperreality 
in Baudrillard's work. According to Baudrillard, a sign threads out and replaces reality in the postmodern world. The sign as a simulacrum does not have a direct relation to reality; it only simulates it, it becomes a cloned reality which exterminates reality. The created or produced hyperreality is more realistic than reality itself. Baudrillard observes an expansion of hyperreality in the accumulation of situations, i.e., imitations. The simulation becomes a principle of organization in the postmodern world. "Today abstraction is no longer that of the map, the double, the mirror or the concept. Simulation is no longer that of a territory, a referential being, or a substance. It is a generation by models of a real without origin or reality: a hyperreal." [12, p. 1].

We may perceive this situation as a late modern revolution in communication, cybernetics and the theory of systems which generates sign systems that are not to cover the reality but to create it from models or codes provided by mass communication. The simulacra are created as a result of multiplication and detachment of the signs from the origin. This non-controlled exuberance is likened to cancer by Baudrillard. It is not possible to talk about an original and a copy or an image in any kind of sense because the original does not exist anymore in this context. The world of hyperreality consists of perceptions whose bases are derived from other perceptions that already do not represent the true reality. This then is the reason why it represents a simulacrum. The objects lost their connection to reality, and they are transformed to hyperreality. The simulacra become the fundamental base to define the world. All relations are artificially created with the help of models produced by the system for the purpose of commodity creation. The simulation which is more real than reality itself leads to duplication of reality and subsequent creation of hyperreality. Baudrillard assumes that reality disappears because it is not possible to distinguish between real and fiction anymore, as the simulation removes the "principle of truth" by canceling the original relation between the significant and signification. Technologies transfer reality into a sign, simulation, and this process leads to disillusion. According to Baudrillard, one of the things that captivates us in hyperreality is technical perfection. However, it is not clear where the reality begins and ends or where begins and ends the fascination of technical perfection which so strictly reproduces reality. "In this sense, the technology digs itself its own grave. For while it perfects the means of synthesis, it makes the criteria for analysis and definition more stringent, with the result that absolute fidelity and exhaustivity in matters of the real becomes evermore impossible. The real is turned into a vertiginous phantasm of exactitude, vanishing into the infinitesimal." [13, p.148]. The technologies absorb illusion about the real world. The result of this is the opposite - disillusion and disappearance. All objects which have been "critically examined" such as history, power, works, dreams, sex - they have taken revenge by the disappearance, and the necessary criticism has disappeared with them. The weak thought is like the last person at a party whose reason to stay is gone in this context. Knowledge of hyperreality includes: "Everything is to be produced, everything is to be legible, everything is to become real, visible, accountable, everything is to be transcribed in relations of force, system of concepts or measurable energy, everything is to be said, accumulated, indexed and recorded, This is sex as it exists in pornography, but more generally, this is the enterprise of our entire culture, whose natural condition is obscene: a culture of monstration, of demonstration, of productive monstrosity." [14, p. 34 - 35]. A "porn culture" in this productive space is controlled by the principle of transparency of powers in the field of visible and countable phenomena: "objects, machines, sexual acts, gross nation product.” [14, p. 35].

Baudrillard deals with these attributes to demonstrate a critique of the contemporary postmodern culture. The porn culture focuses not only on the attributes of sex but on all growing and blind desires and on the satisfaction realized in hyperreality. This simulation is composed of reference sings that will repeat the algorithm of hyperreality to create a new superior hyperreality. The porn culture par excellence as such is the ideology of concreteness, factuality, utility, giving preference to consumer values and material infrastructure of things. An obscenity of such world rests in the fact that nothing is left for imagination, nothing is left to the idea. Everything is transferred to a visible and an inevitable sign. This is a hyperreal world in which entertainment, (dis)information and communication technologies provide not only the most intense experiences and scenes of everyday life but also the codes and models that everyday life structures. But in the non-linear world, the determination itself is random because, in a situation where each individual is confronted with a flood of images, codes, and models each of which can shape our thought, knowledge or behavior, there is no space for mapping the causal mechanisms and logic. The hyperreality is more real than reality, so the models, images, and codes of hyperreality control us. Baudrillard's categories of simulation and hyperreality are connected to reflect a new postmodern situation which requires a new kind of ethics, social theory, politics, etc. The concept of hyperreality is demonstrated through many social, cultural, political and economic phenomena. The technologies through their impact on recipients and their manipulative abilities present signs which do not comply with "reality." In today's material world of consumerism, the real objects are losing their true value; they are replaced by signs which are shapeless, which are everywhere and nowhere at the same time. [15] We are voluntary participants of this imaginary world. This world is constructed artificially, and we are just improving it. All these actions of maximalization result in indifference and uniformity which weaken morality of sociality. And, according to Baudrillard, we will be continuing until the end. It is hard to conclude if Baudrillard is a nihilist, moralist or a visionist of the future. So we decided to conclude this with the words of Martin Kasarda [16] who refers to Baudrillard in the following way: "We are in an era of simulation, and we enjoy it, Mr. Baudrillard. We are part of the game in which we know 
that the work is not productive but it is part of life and the way of slavery, and we also know that the salaries have no rational connection to this work. The signs and codes are multiplying and produce more signs and codes in more and more bizarre spirals and cycles. We are a society organized around simulation, and our being is transferred to role-playing in social games. (...) And narcotized by the ecstasy of media we do not suffer from nostalgia, so the end of the world that has taken place in the meantime, we couldn't give a damn about it. Even so, the end of the world was simulated, and somebody earned it well. "

\section{Conclusion}

The ethical aspects of techno-science, dromology and hyperreality become more and more actual and relevant in today's plural and axiologically unclear era. With the progress of techno-science and new means of communication and media, we appear in some so far not very familiar dimension of being human. Thanks to the progressive expansion of information means we can observe changes in the social-cultural paradigm. The starting point for us was the understanding of the progress of sciences in computerized societies according to Lyotard who pointed out the change of knowledge caused by the development of techno-science. According to Lyotard, knowledge becomes technology dependent. It is obvious that our thought, behavior, and acting is adapted more and more to the changing technical improvements. We agree with Lyotard that while the improvements will uncontrollably progress, this can have an impact on the change of image of the human. Lyotard expresses his concern about the separation of thinking from the body. We give ourselves to technologies, and thus we get rid of the unpredictability of the future which eliminates our thinking, decision making, evaluation and so on. While we were able to control technology, and we enjoyed doing so in the past, we can now observe that the technology is controlling us in the sense that we are even manipulated by it; so we have reached the (cyber)culture of the "inhuman" where the boundaries between "human" and "inhuman" are being erased.

A similar scenario is offered to us by Virilio's concept of dromology. According to Virilio, our perception of time and space changes thanks to the speed that is caused by new technologies. Reality and truth are the falling victims of the overinformatized era. We are withdrawing from our being in the fast virtual worlds. We are deformed by the effects of the "information bomb" which has made us into "tele-narcomans," living in delirious states. In the virtuality or cyberspace, we are intoxicated by a hallucinogenic extra-mixed moloko with the taste of "amnesia." We become disorientated and manipulated under the influence of these "drugs". We have left our control over our being to the "Big Brother" who sees us all the time and everywhere. We are just a "pixel" on the screen. Virilio demonstrated hyperreality as an aesthetic of disappearing where the world and people are crushing to their synthetic skeletons. Our perception of reality is blunted by the speed that overpasses us, so we create an imaginary reality that is "painless."

Thanks to the rapid progress of technologies we abandon the world of imperfection where all ethical judgments will become irrelevant. The world full of images which comply with neither the original nor the copy is the world of hyperreality. We define the world and ourselves by simulacra. This is reflected in the physical, psychological and moral spheres. Reality has disappeared because we are not able to distinguish between the real and the imaginary anymore, between truth and fiction. This is characteristic of this era, which may also be labeled as informational, material, consumer or hedonic. Baudrillard uses the term porn culture to underline the current trends and values. He refers to the overpresenting of obscenity which he sees in inadequate pragmatism, consumerism, and calculation. Everything that is transferred to artificially produced signs and relations becomes relevant. The media and new communication technologies have the dominant position here. We are pulled back to the virtual tele-present where there is no need to think. These technologies have the ability to cancel the distance between reality and fiction. The consequences that can be observed are expressed at both the individual and social levels. We are weak and indifferent. As Koreny points out “(...) the ability to tolerate and excuse everything that reflects the spirit of the modern times actually feeds from the rich source of moral indifference, from the Nietzschean incompetence to moral "Yes" and moral "No"." [17, p. 20]. We got rid of the obligation towards responsibility. Despite all this, despite these frightening implications, we obviously do not blame technological progress as such. But we are convinced that it is extremely important to realize that "reality" and "truth" cannot be found somewhere in a numerical calculation or painless ethics of indifference.

\section{Acknowledgement}

The contribution was created with the financial support of the University Grant Agency UGA I-17-212-02: Disputes over the ethical neutrality of the state under the condition of modern pluralistic societies. 


\section{References}

[1] MCLUHAN, M.: The Gutenberg Galaxy: The Making of Typographic Man. Routledge, London, 1962.

[2] LYOTARD, J. F.: The Postmodern Condition: A Report on Knowledge. University of Minnesota Press, Minneapolis, 1984.

[3] One of the key works of Jean-François Lyotard is known as The Postmodern Condition: A Report on Knowledge (1984). The reason why we have chosen to analyze Lyotard and his work is the author's original approach to post-industrial advanced societies which he describes as post-modern. We will focus on the problem of science in computerized societies and on the understanding of „inhumanity“ in his interpretation. As the author himself proclaims the boundaries between "human” and "technical” are faded which causes a fear of our future. Lyotard formulates his concerns and visions in The Inhuman. Reflections on Time (1991).

[4] TURCAN, C.: Hans Jonas' Ethics of Technology: Risks of Technological Society. Communications - Scientific Letters of the University of Zilina, 19(1), 35 - 38, 2017.

[5] LYOTARD, J. F.: The Inhuman. Reflection on Time. Polity Press, Cambridge, 1991.

[6] VIRILIO, P.: The Information Bomb. Verso, London, New York, 2000.

[7] Paul Virilio is a French philosopher, aesthetician, sociologist, military historian and architect, painter and urban designer, who can also be classified as a postmodern thinker and theorist of post-history. He is also a critic of new technologies and media forms. In his works as The Aesthetics of Disappearance (1991), The Time Machine (1994), and The Information Bomb (2000) and in many others he deals with the phenomenon of speed and elaborates the theory of dromology. His thoughts and visions apply to the social sphere, politics, economy, history, etc.

[8] VIRILIO, P.: The Aesthetics of Disappearance. Semiotext(e), New York, 1991.

[9] Piknolepsia (from the Greek pyknos - frequent, plentiful), is one of the main terms in Virilio's aesthetics of disappearing. In the context of medicine, piknolepsia is children's paroxysmal disease manifested by rhythmic electric discharge in the brain and quick arrival. Clinical symptoms include sudden stopping an activity in progress, usually without losing the previous attitude. Fits are often accompanied by rhythmic motion of the eyelids or lips. The usual duration is 5-10 seconds. Several fits like this can happen daily.

[10] BAUDRILLARD, J.: Simulations. Semiotext(e), New York, 1983.

[11] Jean Baudrillard was one of the most popular critics of contemporary society and culture. He also received labels as a theoretical anarchist or a representative for catastrophic philosophical discourse. He engages in postmodernism as a representative for posthistory theory. Baudrillard's work is really colorful and it's problematic to read it, it is very hard to decide whether it is best to read Baudrillard as a science fiction and pataphysics, or as a social theory and metaphysics of culture, and whether his work from the 1980s should be understood as a sign of truth or fiction.

[12] BAUDRILLARD, J.: Simulacra and Simulation. University of Michigan Press, Michigan, 1981.

[13] BAUDRILLARD, J.: Revenge of the Crystal: Selected Writings on the Modern Object and Its Destiny, 1968-1983. Pluto Press, London, 1999.

[14] BAUDRILLARD, J.: Seduction. New World Perspectives, Montreal, 1990.

[15] Leskova - Valco provide empirical analysis of the influence of mass media on the formation of adolescent identity and they focus on philosophical-ethical reflections in this context, namely they deal with the problem of values, manipulation, information, and others. See: LESKOVA, A. - VALCO, M.: Identity of Adolescents and its Dimensions in the Relation to Mass media: PhilosophicalEthical Reflections. Xlinguae, 10(3), 324 - 332, 2017.

[16] KASARDA, M: Your Virtuality, Jean Baudrillard!/Vasa virtualita, Jean Baudrillard! (in Slovak) [online]. 2010. Available: http:// www.jetotak.sk/listynemtvym/vasa-virtualita-jean-baudrillard.

[17] KORENY, P.: Disputes about Tolerance/Spory o Toleranciu (in Slovak). Difference and Tolerance/Diferencia a tolerancia, VASKO, M. (Pub.), Presov, 15 - 41, 2011. 